\title{
The Effects of Immigration and Integration on European Budgetary Trade-offs
}

\author{
Christine S. Lipsmeyer, Andrew Q. Philips, and Guy D. Whitten
}

February 23, 2017

Please Cite As: Lipsmeyer, Christine S., Andrew Q. Philips, and Guy D. Whitten. 2017. "The effects of immigration and integration on European budgetary trade-offs." Journal of European Public Policy: 1-19.

\begin{abstract}
What affects government policymaking continues to be an important question for researchers interested in political competition and policy priorities. In this paper, we bring together a theoretical framework that focuses on the influence of globalizing forces on government policy decisions with a methodological emphasis on explaining dynamic budgetary trade-offs. While comparative public policy and budgetary scholars typically have focused on entire budgets or amounts spent on specific policies, we look at the political priorities embedded in budgets by modeling the budget as a pie. Then, we theorize about how governments respond to external shocks by altering the allocations to the various policy areas. Using this approach, we find that governments of different ideological types react to external shocks by altering their different policy priorities.
\end{abstract}

KEYWORDS Budgeting; Compositional Data; Globalization; Welfare State Policy

WORD COUNT 7891 
How do external shocks affect governments' budgetary priorities? When explaining policy priorities and government budgets, domestic factors have been at the forefront with scholars emphasizing political ideology, government responsiveness, economic growth, and demographic shifts. However, debates about how the opening of borders and the free movement of labor and capital affect policy priorities (Franzese and Hays 2006) also touch on how globalization influences budgetary trade-offs. How and when do these external forces influence governments' policy allocations, and do governments respond differently to these pressures, depending on their ideological priorities?

With the easing of restrictions on labor markets and the movement of capital, governments must now consider not only their own domestic conditions, but also how globalizing shocks will affect them. Building on recent research, we argue that the way in which governments respond to these external changes will depend on their ideological positions and priorities (Lipsmeyer and Zhu 2011). Given that ideological viewpoints frame governments' policy positions and priori- ties (Hibbs 1977; Hicks and Swank 1992; Blais and Dion 1993; Schmidt 1996; Brauninger 2005; Wenzelburger 2015), these ideological priorities should also shape how governments alter their budgetary priorities in response to external forces. For instance, we would not expect left- and right-leaning governments to respond to global pressures in similar ways, because the priorities of their electoral and partisan supporters should structure their policy reactions. In the face of external shocks, how governments change their budgetary priorities will depend on their ideological orientations.

Relating budgets to policy priorities continues to be a key assumption in budgetary research. To date, most scholars interested in explaining governments' priorities have done so by 
analyzing spending on a single specific policy area—for instance, welfare, unemployment, or defense (Brown and Hunter 1999; Lipsmeyer and Zhu 2011; Whitten and Williams 2011; Wenzelburger 2015). But governments do not decide spending allocations for single policies in a vacuum. Instead, they must trade off competing interests and groups when making budgetary decisions (Franzese 2002).

When altering spending on one policy area, they are shifting resources and changing allocations across multiple policies. In this paper, we propose a theory about how globalizing pressures affect government budgetary behavior differently, depending on their ideological priorities. In other words, we argue that external shocks do not have uniform effects on the allocation of budgetary resources once we take into consideration government ideology.

We make both theoretical and methodological contributions. First, we present a theory that combines expectations about policy priorities and government budgets from work on both political party (or government) institutions, and the effects of globalization. By explaining our expectation that external shocks affect government budgetary behavior differently, depending on their ideologies, we are better able to understand government policymaking. Second, since we are interested in how governments decide budgetary trade-offs between policy categories, we use a compositional modeling framework. We shift the focus from thinking about one policy area in relation to all others to more realistically considering policy areas in relation to others. While this advancement is clearly methodological, it also has theoretical implications. Theorizing and modeling policy priorities relative to each other provides a more holistic picture of budgetary behavior; something that present research lacks.

\section{LITERATURE AND THEORY}


The factors that influence government policymaking remain vital links to understanding political priorities. Governments place varied emphases on policy areas, and much established research has focused on how the ideological and partisan makeups of governments can translate into dissimilar policy visions (e.g., Hibbs 1977; Blais and Dion 1993; Hicks and Swank 1992; Schmidt 1996). To this end, scholars have focused on explaining government budgets and spending on specific policy areas in order to speak to governments' policy priorities. In addition, researchers have considered how globalizing forces can affect the use and role of public policies (e.g., Cameron 1978; Garrett 1998; Burgoon 2001); however, scholars have given less attention to how these external pressures or shocks affect the policy behavior of governments.

Government differences in the form of partisanship or ideology remain a key starting point for research on government budgets and priorities. With researchers studying spending on specific policies or areas, knowing a government's ideological leaning can help explain its behavior on budgets and expenditures (Brown and Hunter 1999; Brauninger 2005; Stasavage 2005; Plumper, Troeger and Winner 2009; Gingrich 2011; Wenzelburger 2015). As this previous research has highlighted, governments of different ideological stripes emphasize different policy programs and budgetary areas - whether because of the socio-demographic or economic characteristics of their supporters or their desires to see specific policies implemented. Since various groups and beneficiaries support different political parties and governments, the resulting government behavior on policies shows these ideological distinctions. For instance, with leftleaning parties relying on their backing of government programs to shore up their support among low and middle income supporters and right-wing parties using lower taxes and government intervention to appease their middle to high income voters, the ideological bent of the government affects its vision of budgetary allocations. 
To build on this extensive research area, the next step is to explain partisan budgetary behavior from a different angle: public policy trade-offs. This involves moving from theorizing about and evaluating how governments alter spending on a policy or policy areas to considering how governments allocate their budgetary resources among the various policy areas. However, as Potrafke (2011) points out, there are few studies that explore the relationship between government ideology and budgetary compositions cross-nationally, and this compositional work typically has budgetary components expressed as a percentage of the whole. ${ }^{1}$ When thinking of governments' budgetary decisions more holistically, the effect of government ideology shifts from affecting one policy area compared to all other areas and instead, reflects trade-offs between policy areas - a more realistic picture of policymaking.

In addition to considering government decisions as trade-offs between policy areas, policymaking also does not occur in an ideological or political vacuum; external factors may affect how a government's ideology influences its behavior on budgetary trade-offs. Similar to recent research that shows how economic and political contexts affect individual attitudes for government policies (Wlezien 1995; Soroka and Wlezien 2010; Gingrich and Ansell 2012; Zhu and Lipsmeyer 2015), broader domestic economic and institutional situations can affect a government's ability to enact ideologically driven changes to policy budgets. From economic downturns (e.g., Perotti and Kontopoulos 2002; Lipsmeyer 2011) to institutional constraints (e.g., Bawn and Rosenbluth 2006; Martin and Vanberg 2013; Back and Lindvall 2015), research has demonstrated that the contexts in which governments decide budgets can make it easier or more difficult for them to succeed in pushing policy priorities in their preferred directions.

In thinking of contexts as affecting individuals' or parties' preferences or behavior, Boix 
(1998) discusses how exogenous shocks can shape political party behavior by altering their preferred policies. However, because parties depend on different groups for electoral support, parties respond to these shocks in diverse ways, depending on their ideological preferences. Rather than explain parties' actions on the supply side; however, these contexts or shocks may affect partisan behavior on budgets.

When considering how context can shape the policy behavior of governments, research has shown that external shocks to domestic situations can affect the relationship between government ideology and policy budgetary decisions. Globalization remains one of the key external contexts or shocks shaping domestic governments' behavior. With the ups and downs of the global economy, the effect of economic downturns on policymaking decisions remains an open-ended question (Boix 1998; Lipsmeyer 2011; Starke, Kaasch and Van Hooren 2014). One policy area that researchers have emphasized has been social policy, where scholars have highlighted how governments either compensate for the hardships of economic openness or use the opportunity to prioritize efficiency and decrease spending (Busemeyer 2009; Burgoon 2001; Garrett 1998; Cameron 1978).

With a focus on economic openness, scholars have argued that a combination of open markets and strong left parties leads to expansionary welfare states (Cusack 1999; Hall and Soskice 2004; Iversen and Casack 2000). Others have found a similar story on the other side of the ideological scale: shifts toward privatization correspond with right-wing government power (Schneider and Hage 2008). While economic openness and the movement of capital can shift government policy priorities, policymakers also may react to other external shocks, such as increases in immigration. Although moving capital across borders remains a key globalizing 
force, the ability of labor to cross borders can affect domestic labor markets and public policy (Borjas, Freeman and Katz 1996; Franzese and Hays 2006). Highlighting how increases in immigration rates have significantly different effects on unemployment benefits under left-wing versus right-wing governments, Lipsmeyer and Zhu (2011) illustrate that the effects of these external pressures on policymaking depend upon the government in power. Their findings suggest that the external effects of immigration and the free movement of labor on unemployment expenditures depend largely on domestic institutions.

While many of the studies mentioned above have explicitly modeled how external factors influence domestic policymaking, they typically focus on a single category of the budget. ${ }^{2}$ Although this is a reasonable modeling decision for getting an initial study of budgeting dynamics, it over- looks the complex trade-offs policymakers make as they prioritize one particular category over some — or all —of the others. In democracies, wholesale rises and cuts in expenditures and revenues are often politically infeasible; instead, governments must often make relative changes to the budget. Despite this basic fact of budgetary trade-offs, we are aware of only two studies that explicitly model this complex trading off of policies in the budgetary process. In the first, Breunig and Busemeyer (2012) examine how increasing fiscal pressures, political institutions, and the interactive effect of the two, affect the budgetary trade-offs between pensions, investment, and labor market expenditures in OECD countries. Two of their most important findings are that social democratic governments do not differ in their spending priorities in any significant way from their counterparts, and that majoritarian systems use discretionary expenditures, while those under proportional representation use large programmatic entitlement spending. In the second, Philips, Rutherford and Whitten (2016) examine the five largest expenditure categories in the US federal budget. They find evidence that as the public 
becomes more liberal, governments are willing to decrease defense expenditures and raise social security expenditures (in the long-run). While these two articles represent a significant advancement over previous modeling strategies by explicitly modeling the comparative budgeting process, neither examines how external economic shocks might influence these tradeoffs.

Viewing government budgetary decisions from a compositional or "trade-off" perspective significantly alters how we approach the relationships between external shocks, government ideology, and budgetary allocations. Governments may desire to alter the composition of budgets to fit their ideological policy priorities; however, their ability to do this may be constrained by external pressures. Bringing together previous research on government decision-making, external forces, and budgetary compositions, we theorize that the way in which globalizing forces shape the composition of budgets will depend on the ideology of the government in power. Since the composition of budgets expresses the relative importance of policy priorities, we expect governments from the left and right to react differently to external shocks and alter budgets in response: either increasing, decreasing, or retaining the status quo proportions. Because we are interested in explaining changes to the composition of budgets (and not levels of spending) in response to external shocks, we consider policies' relative values to both left and right governments. We argue that their overarching ideological priorities, along with their corresponding electoral supporters will lead them to make trade-offs between various policy areas in order to achieve their policy visions. In considering the key differences between governments and parties, we focus on how they desire different roles for the government from those that envision more activist governments to redistribute resources across society to those who argue for less government and more efficient economic policy. From this basic perspective, 
we can turn to deciphering how governments will respond to immigration and integration shocks.

Researchers have discussed globalizing forces or external shocks in various wayscapital mobility, decline of trade barriers, and opening of markets (Rodrik 1998; Cameron 2001; Hall 2001) _ but the emphasis has thus far been on the behavior of capital and firms. More recently, researchers have become interested in how more labor-led globalization forces affect policies with increasing interest in wage levels, immigration, and labor market structures (Lipsmeyer and Zhu 2011; Burgoon 2014; Soroka et al. 2016).

When considering the effects of external shocks on governmental behavior, we discuss how labor market integration and immigration may pressure governmental budgetary behavior in different ways, depending on their ideological viewpoints. Previous literature has found that when faced with rising immigration, left-wing governments increase the generosity of unemployment benefits, but movement towards opening labor markets does not have a similar effect (Lipsmeyer and Zhu 2011). This difference between an external shock in immigration versus one in integration may affect more than unemployment policy; it may have broader ramifications for trade-offs in budgetary priorities. Because political parties and governments differ in the supporters that they shield from the effects of external pressures, we cannot assume that these shocks will have the influence on their budgetary behavior. In response to a shock to integration or immigration, governments should shift budgetary resources between policies in order to reallocate the budget to fit their ideological vision.

In Table 1, we highlight our theoretical expectations about how governments will respond to globalization shocks - immigration through the opening of borders and labor market integration through the opening of employment - by starting with their general priorities (policy 
and electoral). In this first step to match up policy priorities and expected behavior for entire budgets, there is a disconnect between the sharpness of our theoretical expectations and real world budgetary categories; however, we argue that this a step in the right direction. Building on previous research, we consider how governments will alter budgetary compositions when faced with external shocks from immigration and integration. For left governments, we expect that they will be more responsive to changes in immigration; with their ideological and electoral ties to workers and labor unions, these changes to the labor force will push left governments' to shield their supporters. Therefore, we expect that governments on the left generally will prefer policies that buffer segments of society from the instabilities of the labor market, so they will allocate budgetary resources toward redistributive policy areas. Alternatively, right governments will prioritize policies that support less government intervention and market efficiency, as well as those that generally favor capital and business. A shock to that leads to more integrated economic markets, then, will more likely influence these governments to reallocate budgetary resources in order to shore up their priority of market efficiency. Interestingly, an additional budget category that we expect the right to prioritize is health care. As Jensen (2011) has explained with his "marketization via compensation" argument, in order to attract electoral support, right-wing governments will tend to increase health care spending, while expanding private options. We thus expect governments from both left and right to respond to integrative shocks with increased health care spending, albeit for different reasons.

\begin{tabular}{|l|l|l|}
\hline & Left & Right \\
\hline General Priority & Labor (redistribution) & Capital and Business (efficiency) \\
\hline
\end{tabular}




\begin{tabular}{|l|l|l|}
\hline Most Responsive To & Immigration & Labor Market Integration \\
\hline Prioritized Budget Categories & $\begin{array}{l}\text { Social Protection, Public Services, } \\
\text { Housing, Health }\end{array}$ & Economic Policy, Health \\
\hline
\end{tabular}

Table 1: Theorized Expectations to Integrative Shocks

Specifically, for a shock in immigration, we expect that the left will be more reactive, shifting budgetary priorities toward those redistributive policies that buffer their supporters during economic trials - social protection, public services, health care and housing. The right, however, will not shift their priorities in response to an immigration shock, so these governments will not tradeoff budgets on economic policies for redistributive policies; they will hold their course. For a shock toward market integration and the opening of markets, we contend that the partisan pattern will be the opposite. Left governments will hold their budgetary course (i.e., they do not alter the budget's composition). ${ }^{3}$ They continue to offset the labor market instability through their redistributive policies. Right governments will react to the shock by shifting their policy priorities toward more market-driven policies and away from redistributive ones. Importantly, without considering why governments make trade-offs between policy areas, key aspects remain unconsidered in our theorizing about what affects the policymaking process.

\section{DATA AND METHODS}

In order to test our theoretical claims about how external shocks affect governmental behavior on budgetary trade-offs, we gathered data on 15 developed European countries from 1980 to 2007. ${ }^{4}$ This set of countries and years enables us to examine the impact of different types of external 
shocks, so here, we are able to investigate how governments of varying ideological bents react to shifts in immigration and integration.

Since we are interested in explaining budgetary trade-offs, our dependent variable is the pro- portion of the budget spent on policy areas. We used data from the International Monetary Fund's Government Finance Statistics (GFS) and relied on their classification of the eight largest budget categories: public services, defense, economic affairs, housing, health, recreation, education, and social protection. Detailed descriptions of these categories are available in the Appendix. Our dependent variable is thus a compositional variable which we label $y_{i t j}$ to represent the proportion of the budget in country " $\mathrm{i}$ " at time " $\mathrm{t}$ " that is allocated to budget category “j." As such, in any country-year, $0<y_{i t j}<1$ and $\sum y_{i t j}=1$. While this type of variable is ideal for modeling budgetary trade-offs, as we discuss below, estimating and interpreting the relationships between our independent variables and $y_{i t} j$ requires some care.

To measure external shocks from a globalization perspective, we include two main independent variables in our analysis: the change in labor market integration and the immigration rate. For each, we need measures that are continuous and measured in the same fashion across countries and over time. Since we theorized that governments react differently to the movement (or lack thereof) of labor, our immigration measure - net immigration — comes from the OECDs International Migration Statistics and is calculated for each country-year as the difference in the outflow of immigrants from the inflow of immigrants, divided by 1000 (OECD 2009).

In order to test our argument that governments react differently to integrating labor markets, we use a measure that relies on the rule of one price: "In the presence of a competitive market structure and in the absence of transport costs and other barriers to trade, prices of 
homogenous products sold in different markets would converge to "one price" because of market forces (Lipsmeyer and Zhu 2011, p. 651). Therefore, labor markets that are more integrated would converge toward the same prices for labor or wages. To measure labor market integration using this criteria, we rely use the measure from Lipsmeyer and Zhu (2011, p. 652), given as:

$$
\Delta \text { Integration }=\Delta\left(1-\frac{X_{i t}}{M_{t}}\right)
$$

where

$$
X_{i t}=\mid \text { Average Unit Labor } \text { Cost }_{t}-\text { Unit Labor Cost }{ }_{i t} \mid
$$

and

$$
M_{t}=\max _{i}\left(X_{i t}\right)
$$

Thus Equation 1 is the change (between time $t$ and $t-1$ ) of one minus the absolute difference be- tween the average labor cost at time $t$ (across all countries) minus the unit labor cost of a particular country $i$, normalized by dividing by the maximum value of $X_{i t}$ for each time $t$. This ensures that the raw series is bounded by zero and one; values close to zero represent countries with relatively low levels of economic integration.

For the ideological leaning of governments, we use Seki and Williams (2014)'s extension of Woldendorp and Budge (2000)'s measure of the "Ideological Complexion of Government and Parliament." Woldendorp and Budge (2000)'s CPG measure ranges from 1 for governments that are dominated by politicians from the right to 5 for governments that are dominated by politicians from the left. We follow the lead of other papers, (e.g., Powell and Whitten 1993) and collapse the measure, so values less than or equal to two are classified as "right" and all others 
are classified as "left." To test our hypotheses, we need to interact this measure with multiple other indicators, so we collapse it into a dichotomy. ${ }^{5}$ Although other measures of government ideology, such as party families or party positions (e.g., the Comparative Manifestos Project) offer more dimensions and detail, this more traditional measure makes interpretation of the results easier at this stage with our data. In future work, with more data, we would like to use a more nuanced and perhaps multidimensional measure of ideology that would be better able to pull apart parties and governments on non-economic dimensions.

In explaining budgets, we also include a number of control variables. To account for variation in nations' economic conditions, we use the national unemployment rate (World Bank Development Indicators), the inflation rate (World Bank Development Indicators), and the openness of a country's economy (Penn World Tables). The age dependency ratio is the proportion of a country's population under 18 and over 65 years of age (OECD) and controls for the reliance of the population on government resources. Finally, following others' research on policy priorities and political influence, we control for the union density as a reflection of the wage bargaining power in a country (Wallerstein, Golden and Lange 1997).

To test our theoretical claims about budgetary trade-offs, we draw on recent work that employs log-ratio transformations in order to model all eight components of the budget simultaneously (Breunig and Busemeyer 2012; Philips, Rutherford and Whitten 2015, 2016). Since all eight categories sum to one, modeling them together using standard regression models is highly problematic. To get around this, current models of compositional dependent variables use a strategy proposed by Aitchison (1982). It involves taking the logged ratio of $J-1$ categories relative to an arbitrary "baseline" category, $j=1$ (without loss of generality): 


$$
s_{i t j}=\ln \left(\frac{y_{i t j}}{y_{i t 1}}\right) \forall j \neq 1
$$

This "unbounds" the series from the zero-to-one space. This modeling strategy is preferable to more complex alternatives, such as beta regression, since we can use standard regression approaches for estimation (e.g., multivariate normal), and obtain all results simultaneously, once we "un-transform" the $J-1$ compositions back into $J$ categories post-estimation. In order to correct for-and take advantage of - likely correlations in the errors across equations, we estimate the equations defined below using a seemingly unrelated regressions procedure in order to gain more efficient estimates (Zellner 1962). Here, we transform the eight budget categories into seven $s_{i t} j$ log-ratio compositions and estimate the following model specification:

$$
s_{i t j}=f\left(\left(s_{i t-1 j}+\Delta \mathrm{Int}_{i t}+\Delta \mathrm{Imm}_{i t}+\text { Controls }\right)\left(1+\text { Right }_{i t}\right)+\varepsilon_{i t j}\right)
$$

where

- $s_{i t j}$ is the $\log$-ratio of dependent variable category " $\mathrm{j}$ ” for $j>1$ relative to baseline category $j=1$ at time " $\mathrm{t}$ " for country $i$,

- $s_{i t-1 j}$ is a lagged dependent variable. We include this to take into account that the fact that budgets tend to shift incrementally. Another advantage of including a lagged dependent variable is the ability to obtain both short- and long-run effects of the independent variables,

- $\Delta \mathrm{Int}_{i t}$ is our measure of integration,

- $\Delta \mathrm{Imm}_{i t}$ is our measure of immigration,

- Right ${ }_{i t}$ is a dummy variable equal to " 1 " if the party or coalition in government is right- 
leaning,

- and Controls is a vector of controls.

From this model specification, we can see that we have interacted our measure of government ideology with all of the other independent variables in our model and the lagged dependent variable. This corresponds with our theory that the ways in which governments react to external and internal shocks are shaped by their ideological leaning.

\section{RESULTS}

Since we have seven equations and our theory dictates extensive interactions, our estimates yield a rather large number of parameters. Interpretations of these parameters are further complicated by the fact that each of the dependent variables across our equations is a log-ratio. In order to get a clearer picture of how governments make budgetary trade-offs in response to external shocks, we follow the advice of Philips, Rutherford and Whitten (2016) and use graphical depictions instead of presenting our results in a table, which can be found in the Supplemental Materials. ${ }^{6}$ These dynamic simulations of "change from baseline" scenarios help to get a better sense of the short- and long-run effects of shocks in immigration and integration across budgetary categories from changes in our independent variables.

Figures 2a, 2b, 3a, and $3 \mathrm{~b}$ all begin with each of our continuous variables set at their sample mean value and show the expected portion of the budget that would be allocated to a particular budgetary cate- gory depending on the ideology of the government for a four-year baseline period. Then, in year five of each scenario, we change the value of one independent variable and see how the expected trajectory of spending on each category evolves over time. In 
lagged dependent variable models, a one-unit change in an independent variable has both shortand long-run effects. The short-run effect is simply the coefficient on the independent variable; in our case, there is also the interactive coefficient between the independent variable and the Right $_{i t}$ dummy variable. The long-run effect, or the accumulated effect of a change in an independent variable on the dependent variable, is a function of the constituent and interactive terms on the independent variable divided by one minus the coefficient on the lagged dependent variable. Although it is common to calculate these effects, we instead show them in plots of the expected values, since we update the value of the lagged dependent variable at time $t$ with the expected value at time $t-1$, along with $95 \%$ confidence intervals. We can thus make a series of interpretations about whether spending changes significantly across the time of the scenario for a particular category (whether or not two spending intervals for the same category overlap vertically across time) and/or whether expected spending on any two categories is significantly different at the same time in the simulation. For clarity, we also present "effect plots" that show the instantaneous and long-run change net of the average value of each budget category in our sample. Figure $2 \mathrm{c}$ provides a summary of the estimated long-run changes in each category from Figures $2 \mathrm{a}$ and $2 \mathrm{~b}$. Figure $3 \mathrm{c}$ does the same for Figures $3 \mathrm{a}$ and $3 \mathrm{~b}$. Akin to marginal effects plots, these make evaluating the statistical and substantive significance of the results slightly easier.

To show how left and right governments respond to a shock in immigration, we first simulate an increase in immigration in year five under a left-wing government in Figure 2a. ${ }^{7}$ Social services receives the largest increase in its proportion, and this priority continues in the long run. Other policy priorities, evidenced by increased proportions, include public services and economic policy, as well as defense. Declining priorities after the shock are health and education with the proportions allocated to recreation and housing remaining stable. 


\section{[Figure 2 About Here]}

We see a different pattern in Figure $2 b$ when we investigate the right's budgetary behavior after the same immigration shock in year 5. For seven of the eight budgetary categories, the right does not significantly alter its proportions across the simulated period: social services, education, health care, housing, recreation, defense, and public services. In the long term, there is a small but statistically significant increase in the proportion for economic policy. As the simulation shows, there is little budgetary movement for right governments in the face of a shock in immigration.

In Figure 2c, we clarify the differences between the left and right government responses to shocks in immigration by displaying the estimated long-run changes from the baseline scenarios for each budgetary category under a left and right government. ${ }^{8}$ Comparing the top and bottom graphs in this figure, as expected, the left does make substantially larger changes to budgetary allocations than the right in response to an increase in immigration. While the right makes slight alterations to their budgets in the long-term, they appear to be less reactive to the immigration shock. For left governments, the results correspond with our expectations for shifting budgetary priorities toward social protection and public services; however, the long-run negative shifts in housing and health are contrary to our expectations.

Second, we are interested in how changes to labor market integration affects governmental behavior on budgets. In Figure 3a, we present results that show the changing budgetary composition for a left government after a shock in labor market integration at year 5 , and this graphical simulation of our results highlights both the short- and long-term effects of integration. Left governments decrease the proportions of the budget on some policy areas 
(social protection and public services), while increasing those on others (health, education, and economic policy). However, it is interesting to note that few of these changes are immediately statistically significant and that most of these trade-offs only become statistically significant from their starting proportions over a relatively long period of time.

\section{[Figure 3 About Here]}

We display the simulated results for a right government's budgetary reactions to an integration shock in Figure $3 \mathrm{~b}$ and see substantially more shifts here. While many changes to policy areas are similar to those we witnessed above by a left government, such as decreased proportions for social protection and public services and increases for health and education, the shifts are much larger and occur more quickly for right governments. The reactions by the right to increases in labor market integration show larger trade-offs between policy areas. For example, the budgetary allotments for social protection and economic policy see substantial long-term decreases, while education and health care have substantial gains. In response to a shock in labor market integration, left governments make smaller budgetary trade-offs, while the right takes the opportunity to make considerable changes that mostly correspond with their policy priorities. The main exception to this is the significant decline in spending on economic policy. We can see these patterns and a more direct comparison between left and right in Figure $3 \mathrm{c}$, where we display the estimated long-run changes from the baseline scenario for each budgetary category under a left and right government in the face of a positive change in integration. $^{9}$

Considering the results together from the immigration and integration shocks, we find that governments of different ideological propensities react differently to external shocks. 
Government responses depend on their ideologies and the type of shock. In the face of an immigration shock, left governments shift their budgetary priorities to better buffer individuals in the labor market that results in expanded priorities for social and public services in general. However, right governments change their priorities towards economic policy and health care. When we move to looking at a shock in labor market integration, governments' responses varied. Right governments responded by altering their budgetary priorities to fit their preferencesdecreasing social protection and economic policy—but left governments' reactions were more muted, with smaller shifts away from social protection and public services and toward health and economic policy.

\section{CONCLUSIONS AND FUTURE DIRECTIONS}

Public policymaking involves governments making trade-offs between various interests, groups, and priorities. While previous scholars have acknowledged this framework of government behavior, few have actively tackled these relationships either theoretically or empirically. With the introduction of an empirical approach that allows researchers to investigate these decisions between budgetary categories, we now can scrutinize government behavior more closely. Ultimately, in this paper, we are interested in how governments alter their policy priorities after an external shock. We find that governments of different ideological leanings react differently when the shock comes from immigration or integration.

Specifically, we advance work on budgets and globalization in two important ways. First, we theorize and empirically model governmental behavior on budgetary compositions over time, taking into account the trade-offs between policy areas. While focusing on one or two policy areas improves our insights on those areas, we argue that our approach of acknowledging that 
increasing (or decreasing) budgets for some policy areas can limit (or improve) the ability to change other policies' budgets. Here, we are focused on explaining when governments will act and whether their actions are related to their ideological preferences.

Second, from previous research on globalization and public policy, there remains a debate about whether external forces can affect public policy spending. Here, we tackle the issue of how external shocks may affect governments' budgetary behavior across policy areas by incorporating both immigration and integration into our argument. Opening borders to business and capital may affect governments differently than increases in immigration, so we consider governments' responses to these two types of shocks by focusing on their budgetary priorities. Interestingly, we find that the right and left do not respond to both types of external shocks equally, and this has ramifications for scholars' thinking about how globalization forces shape (or do not shape) policy spending, policy priorities, and governmental behavior in general.

The work in this paper offers many avenues for future exploration—-both theoretically and empirically. Theoretically, how governments trade off policy priorities involves questions of government responsiveness, and combining these various pieces of the representative link will be important for understanding strategic government behavior. Empirically, considering budgets and spending from a compositional viewpoint allows for more rigorous and realistic research on political behavior.

\section{BIBLIOGRAPHICAL NOTES}

Christine S. Lipsmeyer is Associate Professor at the Department of Political Science, Texas A\&M University, United States. Andrew Q. Philips is Assistant Professor at the Department of 
Political Science, University of Colorado at Boulder, United States. Guy D. Whitten is Professor at the Department of Political Science, Texas A\&M University, United States.

\section{ADDRESS FOR CORRESPONDENCE}

Christine S. Lipsmeyer, Department of Political Science, Texas A\&M University, 2010 Allen

Building, 4348 TAMU, College Station, TX 77843-4348 (lipsmeyer@tamu.edu). Andrew Q.

Philips, Department of Political Science, University of Colorado at Boulder, UCB 333, Boulder, CO 80309-0333 (andrew.philips@,colorado.edu). Guy D. Whitten, Department of Political Science, Texas A\&M University, 2010 Allen Building, 4348 TAMU, College Station, TX 77843-4348 (g-whitten@pols.tamu.edu).

\section{ACKNOWLEDGEMENTS}

An earlier version of this paper was presented at the conference on, "Political Budgeting Across Europe," which was held at Texas A\&M University, December 10-11, 2015. The authors thank the members of this audience, two reviewers, and the editors for their helpful comments.

\section{NOTES}

1. Breunig and Busemeyer (2012) are one exception.

2. Exceptions include Citi (2013) and Epp, Lovett and Baumgartner (2014.

3. We do not have theoretical expectations for all policy areas in a budget since government ideology may not have different effects for all areas. For instance, research on education spending has highlighted a lack of influence from ideological divisions (Busemeyer, Franzmann and Garritzmann 2013; Garritzmann and Seng 2016). An advantage to using a compositional approach is that it will show the changes—or the lack thereof-in all 
budgetary categories.

4. Austria, Belgium, Denmark, Finland, France, Germany, Greece, Ireland, Italy, the Netherlands, Norway, Portugal, Spain, Sweden, and the United Kingdom.

5. Details available at http://faculty.missouri.edu/williamslaro/govtdata.html (Seki and Williams 2014).

6. We address non-stationarity and autocorrelation issues in the Supplemental Materials.

7. For both immigration and integration shocks, we use two standard deviation increases that fall within our sample of country-years. Each "shock" is a one-time, permanent increase in either immigration or integration in year five, all else constant. Since each variable is expressed as either the change in immigration or integration, this results in a permanent increase in the rate of change.

8. The changes depicted in Figure $2 \mathrm{c}$ and $3 \mathrm{c}$ are the expected total long-run change in each category. The changes that we observe in Figures $2 a, 2 b, 3 a$, and $3 b$ are from 15 years of simulated changes. The long-run changes will be slightly larger in magnitude with tighter confidence intervals.

9. Confidence intervals are wider for the right government results since only about 20 percent of the country-years of our sample were during right governments.

\section{REFERENCES}

Aitchison, John. 1982. "The statistical analysis of compositional data." Journal of the Royal Statistical Society. Series B (Methodological) 44(2):139-177.

Back, Hanna and Johannes Lindvall. 2015. "Commitment Problems in Coalitions: A New Look at the Fiscal Policies Of Multiparty Governments." Political Science Research and Methods 
3(01):53-72.

Bawn, Kathleen and Frances Rosenbluth. 2006. "Short Versus Long Coalitions: Electoral Accountability and the Size of the Public Sector.” American Journal of Political Science 50:251265.

Blais, Andre, Donald Blake and Stephane Dion. 1993. "Do Parties Make A Difference?” American Journal of Political Science 37:40-62.

Boix, Carles. 1998. Political Parties, Growth and Equality: Conservative and Social Democratic Economic Strategies in the World Economy. New York, NY: Cambridge University Press.

Borjas, George J., Richard B. Freeman and Lawrence F. Katz. 1996. "Searching for the Effect of Immigration on the Labor Market.” The American Economic Review 86(2):246-251.

Brauninger, Thomas. 2005. “A partisan model of government expenditure.” Public Choice 125(3-4):409-429.

Breunig, Christian and Marius Busemeyer. 2012. "Fiscal Austerity and the Trade-Off Between Public Investment and Social Spending.” Journal of European Public Policy 19:921-938.

Brown, David S. and Wendy Hunter. 1999. "Democracy and Social Spending in Latin America, 1980-1992." American Political Science Review 93:779-790.

Burgoon, Brian. 2001. "Globalization and Welfare Compensation: Distangling the Ties and Binds.” International Organization 55(3):509-551.

Burgoon, Brian. 2014. "Immigration, Integration, and Support for Redistribution in Europe." 
World Politics 66(03):365-405.

Busemeyer, Marius R. 2009. "From myth to reality: Globalisation and public spending in OECD countries revisited." European Journal of Political Research 48(4):455-482.

Busemeyer, Marius R, Simon T Franzmann and Julian L Garritzmann. 2013. "Who owns education? Cleavage structures in the partisan competition over educational expansion." West European Politics 36(3):521-546.

Cameron, David. 2001. "Unemployment, Job Creation, and Economic and Monetary Union". In Unemployment in the New Europe, ed. Nancy Bermo. New York, NY: Cambridge University Press pp. $7-51$.

Cameron, David R. 1978. "The expansion of the public economy: A comparative analysis." American political science review 72(04):1243-1261.

Citi, Manuele. 2013. “EU budgetary dynamics: incremental or punctuated equilibrium?” Journal of European Public Policy 20(8):1157-1173.

Cusack, Thomas R. 1999. "Partisan Politics and Fiscal Policy." Comparative Political Studies 32(4):464-486.

Dreher, Axel, Jan-Egbert Sturm and Heinrich W Ursprung. 2008. “The impact of globalization on the composition of government expenditures: Evidence from panel data." Public Choice 134(3- 4):263-292.

Epp, Derek A, John Lovett and Frank R Baumgartner. 2014. "Partisan Priorities and Public Budgeting." Political Research Quarterly 67(4):864-878. 
Franzese, Robert J. 2002. Macroeconomic Policies of Developed Democracies. Cambridge University Press.

Franzese, Robert J and Jude C Hays. 2006. "Strategic Interaction among EU Governments in Active Labor Market Policy-making Subsidiarity and Policy Coordination under the European Employment Strategy.” European Union Politics 7(2):167-189.

Garrett, Geoffrey. 1998. Partisan Politics in the Global Economy. Cambridge, MA: Cambridge University Press.

Garritzmann, Julian L and Kilian Seng. 2016. "Party politics and education spending: challenging some common wisdom.” Journal of European Public Policy 23(4):510-530.

Gingrich, Jane. 2011. Making Markets in the Welfare State. New York, NY: Cambridge University Press.

Gingrich, Jane R. and Ben W. Ansell. 2012. "Preferences in Context: Micro Preferences, MacroContexts and the Demand for Social Policy." Comparative Political Studies 45(12):1624-1654.

Hall, Peter A. 2001. ’Organized Market Economics and Unemployment in Europe: Is It Finally Time to Accept Liberal Orthodoxy?". In Unemployment in the New Europe, ed. Nancy Bermo. New York, NY: Cambridge University Press pp. 52-86.

Hall, Peter A. and David Soskice. 2004. Varieties of Capitalism: the Institutional Foundations of Comparative Advantage. New York, NY: Oxford University Press.

Hibbs, Douglas A. 1977. "Political Parties and Macroeconomic Policy.” American Political Science Review 71:1467-1487. 
Hicks, Alexander and Duane Swank. 1992. "Politics, Institutions, and Welfare Spending in Industrialized Democracies, 1960-1982.” The American Political Science Review 86(3):658-674.

Iversen, Torben and Thomas R. Casack. 2000. "The Causes of Welfare State Expansion: Deindustrialization or Globalization." World Politics 52(3):313-349.

Jensen, Carsten. 2011. "Marketization via compensation: health care and the politics of the right in advanced industrialized nations." British Journal of Political Science 41(04):907-926.

Lipsmeyer, Christine S. 2011. "Booms and Busts: How Parliamentary Governments and Economic Context Influence Welfare Policy.” International Studies Quarterly 55(4):959-980.

Lipsmeyer, Christine S and Ling Zhu. 2011. "Immigration, globalization, and unemployment benefits in developed EU states." American Journal of Political Science 55(3):647-664.

Martin, Lanny W. and Georg Vanberg. 2013. "Multiparty Government, Fiscal Institutions, and Public Spending.” The Journal of Politics 75(4):953-967.

OECD. 2009. Unit Labor Costs: Annual Indicators. Oecd.stat ed. Organization for Economic Co-operation and Development.

Perotti, Roberto and Yianos Kontopoulos. 2002. "Fragmented Fiscal Policy." Journal of Public Economics 86(2):191-222.

Philips, Andrew Q, Amanda Rutherford and Guy D Whitten. 2015. “The Dynamic Battle for Pieces of Pie-Modeling Party Support in Multi-Party Nations." Electoral Studies 39:264-274.

Philips, Andrew Q, Amanda Rutherford and Guy D Whitten. 2016. "Dynamic pie: A strategy for 
modeling trade-offs in compositional variables over time." American Journal of Political Science 60(1):268-283.

Plumper, Thomas, Vera E Troeger and Hannes Winner. 2009. "Why is There no Race to the Bottom in Capital Taxation?" International Studies Quarterly 53(3):761-786.

Potrafke, Niklas. 2011. "Does government ideology influence budget composition? Empirical evidence from OECD countries." Economics of Governance 12(2):101-134.

Powell, G. Bingham and Guy D. Whitten. 1993. "A Cross-National Analysis of Economic Voting: Taking Account of the Political Context." American Journal of Political Science $37: 391-414$.

Rodrik, Dani. 1998. “Why Do More Open Economies Have Bigger Governments?” Journal of Political Economy 106(5):997.

Schmidt, Manfred G. 1996. "When parties matter: A review of the possibilities and limits of partisan influence on public policy." European Journal of Political Research 30(2):155-183.

Schneider, Volker and Frank M Hage. 2008. "Europeanization and the Retreat of the State." Journal of European Public Policy 15(1):1-19.

Seki, Katsunori and Laron K Williams. 2014. "Updating the Party Government data set." Electoral Studies 34:270-279.

Soroka, Stuart N. and Christopher Wlezien. 2010. Degrees of Democracy: Politics, Public Opinion and Policy, Cambridge. Cambridge: Cambridge University Press. 
Soroka, Stuart N, Richard Johnston, Anthony Kevins, Keith Banting and Will Kymlicka. 2016. “Migration and welfare state spending.” European Political Science Review 8(02):173-194.

Starke, Peter, Alexandra Kaasch and Franca Van Hooren. 2014. "Political parties and social policy responses to global economic crises: Constrained partisanship in mature welfare states." Journal of Social Policy 43(02):225-246.

Stasavage, David. 2005. "Democracy and Education Spending in Africa." American Journal of Political Science 49:343-358.

Wallerstein, Michael, Miriam Golden and Peter Lange. 1997. "Unions, Employer Associations, and Wage-Setting Institutions in Northern and Central Europe, 1950-1992." Industrial and Labor Relations Review 50(2):379-401.

Wenzelburger, Georg. 2015. "Parties, Institutions and the Politics of Law and Order: How Political Institutions and Partisan Ideologies Shape Law-and-Order Spending in Twenty Western Industrialized Countries.” British Journal of Political Science 45(03):663-687.

Whitten, Guy D. and Laron K. Williams. 2011. "Buttery Guns and Welfare Hawks: The Politics of Defense Spending in Advanced Industrial Democracies." American Journal of Political Science 55:117-134.

Wlezien, Christopher. 1995. “The Public as Thermostat: Dynamics of Preferences for Spending." American Journal of Political Science 39(4):981-1000.

Woldendorp, Jaap, Hans Keman and Ian Budge. 2000. Party Government in 48 Democracies (1945-1998). London: Kluwer Academic Publishers. 
Zellner, A. 1962. "An efficient method of estimating seemingly unrelated regressions and tests for aggregation bias." Journal of the American Statistical Association 57:348-368.

Zhu, Ling and Christine S Lipsmeyer. 2015. "Policy Feedback and Economic Risk: The Influence of Privatization on Social Policy Preferences." Journal of European Public Policy 22:1489- 1511. 

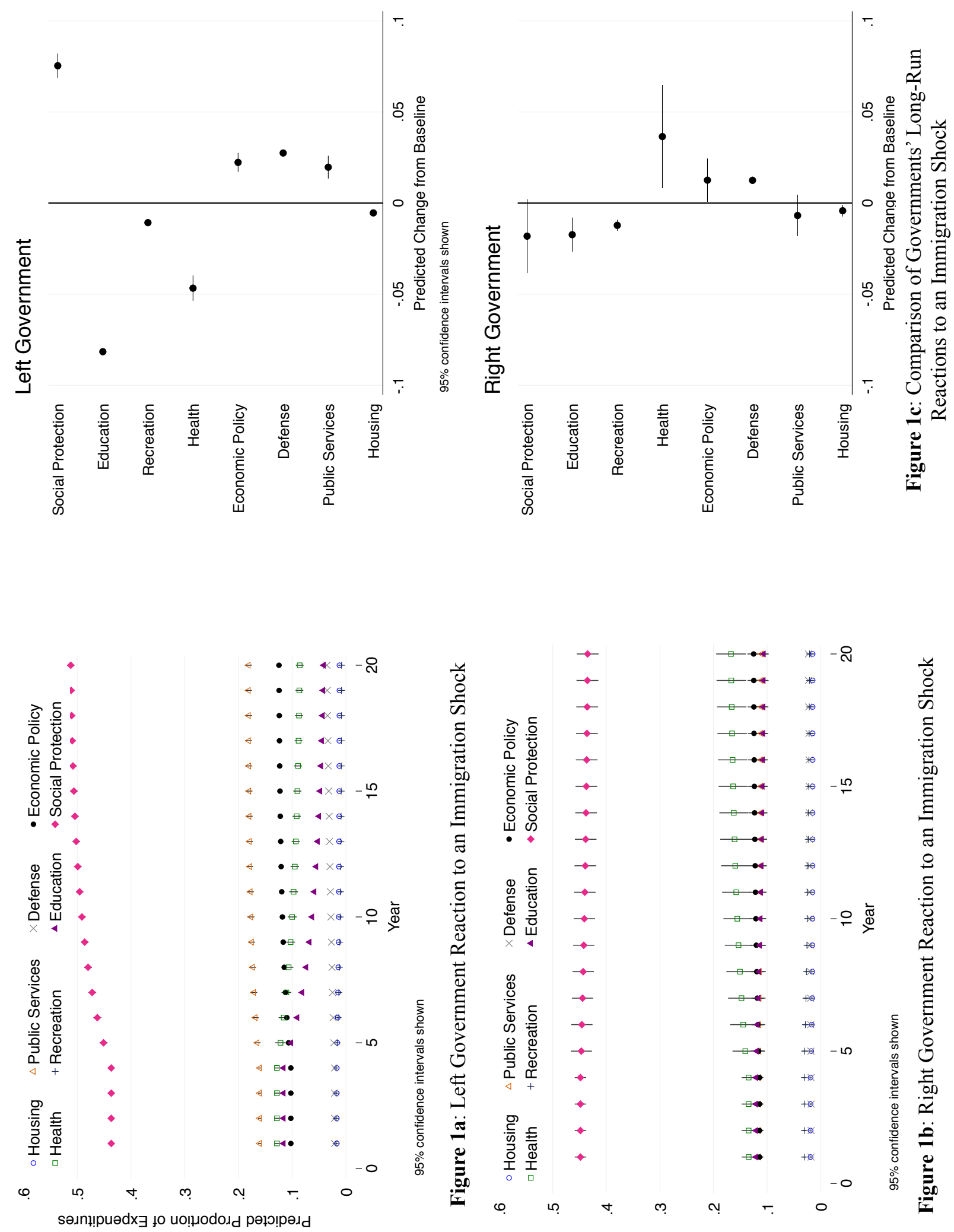

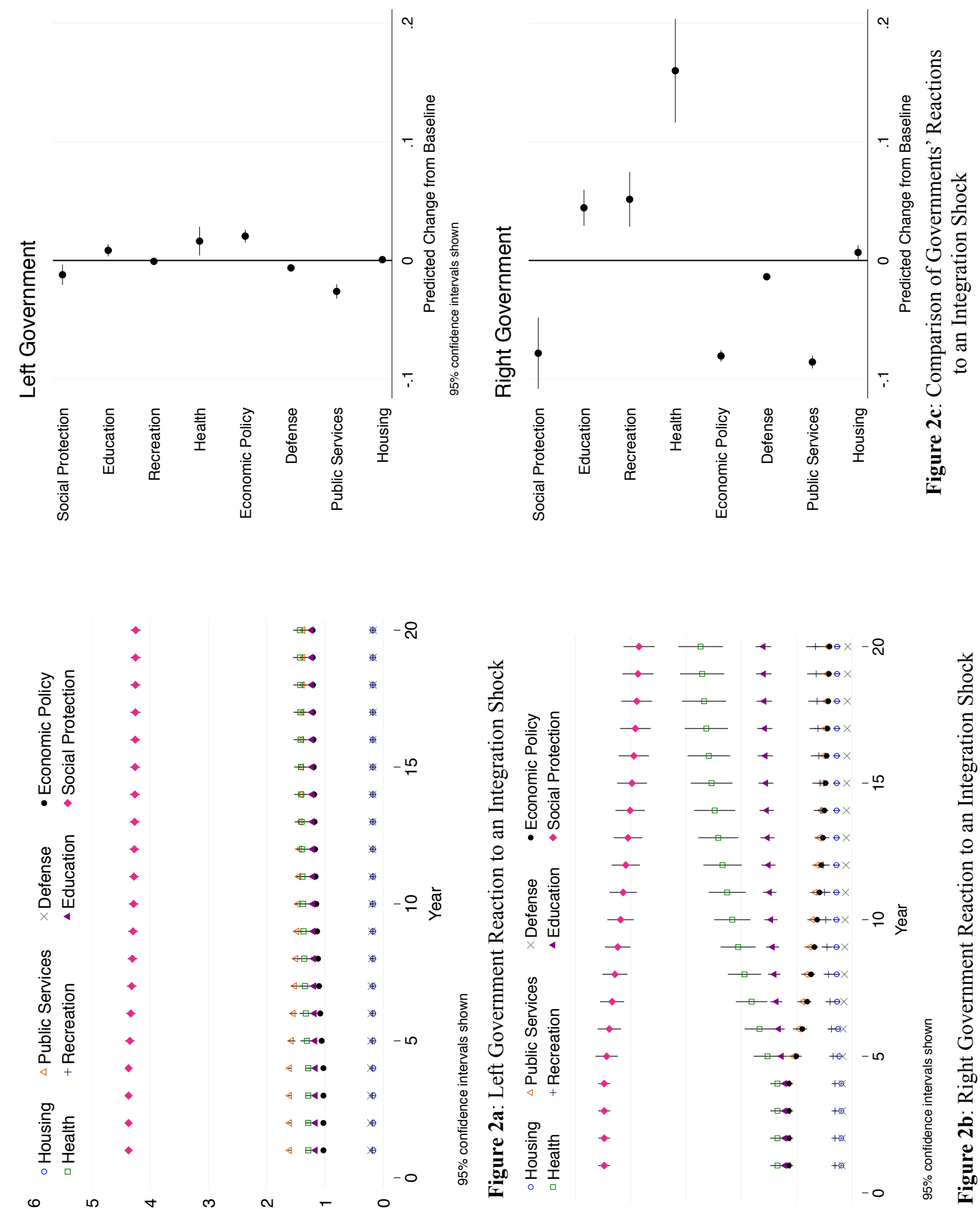

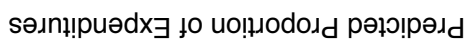

